\title{
Nanoteknoloji ve geleceğin çevreci polimeri nanoselüloz
}

\author{
Nadir YILDIRIM (Orcid:0000-0003-2751-9593) $)^{1 *}$ \\ ${ }^{1}$ Bursa Teknik Üniversitesi, Orman Fakültesi, BURSA \\ *Sorumlu yazar/Corresponding author: nadir.yildirim@btu.edu.tr, Geliş tarihi/Received: 30.04.2018, Kabul tarihi/Accepted: 27.06.2018 \\ $\ddot{\mathrm{O} z}$ \\ Her alanda etkin ve ilerici değişikliklerin oluşturulmasında itici bir güç olan nanoteknoloji, orman ürünleri sek- \\ töründe de kendine yer bulmaya başlamıştır. Özellikle son yıllarda nanobilimi, malzeme bilimi ve orman ürünleri \\ biliminin multidisipliner bir yapı ile ortaklaşa çalışması yeni nesil kompozit malzemelerin, biyokompozitlerin ve \\ nanokompozitlerin geliştirilmesinde büyük rol oynamıştır. Geliştirilen bu inovatif malzemeler geleneksel malze- \\ melerin yerini almakta ve geleneksel üretim tekniklerinin, makinelerinin de rollerini değiştirmesini ve kendini \\ güncellemesini sağlamaktadır. Ağaç malzemenin bileşenlerinden birisi olan selüloz kendi içerisinde birbirine bağlı \\ nano boyutta yapıtaşlarına sahiptir. Nanoselüloz adı verilen bu yapıtaşları saç kalınlığının yaklaşık 10 binde biri \\ küçüklügünde lifleri ve partikülleri içermektedir. Nanoselüloz ağaç malzemeye mekaniksel gücünü veren doğal, \\ yenilenebilir ve mucizevi bir polimerdir. Doğal polimerik yapısı birçok uygulamada kullanılmasına olanak sağlayan \\ nanoselüloz günümüzde otomotiv, elektronik, inşaat ve ambalajlama gibi sektörlerde kullanılmaya başlanmıştır. \\ Nanoselüloz, hafif olmasına karşın sağladığı yüksek performans özellikleri ile endüstri ve akademi tarafından ilgi \\ gören, geleceğin değerli malzemelerinden birisi olarak kendine yer oluşturmaya başlamıştır.
}

Bu çalışmada, nanoteknoloji ve geleceğin malzemesi nanoselüloz hakkında son yıllarda yapılmış çalışmalardan detaylı bilgiler derlenmiş ve söz konusu malzemelerin türleri, üretim teknolojileri, küresel üreticileri ve gelecekteki kullanım alanları hakkında teknik bilgiler paylaşılmıştır.

Anahtar Kelimeler: Nanoteknoloji, nanoselüloz, nanokompozit, ahşap, polimer

\section{Nanotechnology and the futurist green polymer, nanocellulose}

\begin{abstract}
The nanotechnology that produced innovative changes in many industries has been getting attention in the forest products industry as well. Especially, the increase in multidisciplinary studies motivated researchers to work and study on new-generation nanocomposites and biocomposites that will be a strong alternative to traditional materials with the value-added properties. The cellulose, a crucial component of the trees, is made of small blocks. These blocks which are called nanocellulose contain fibrils and particles. Nanocelluloses are green polymers that have received considerable attention in materials science, engineering research, and research \& product development fields in the industry. Nanocellulose is a bio-nano polymer that is widely used as reinforcing materials and added to polymer matrices to create innovative nanocomposites for use in many industries. Today, nanocellulose materials have been used in automotive, packaging, pharmaceutical, insulation and construction industries. The enhancements in the nanocellulose manufacturing processes, the increase in the number of global producers, and the increased demand for green and eco-friendly materials have made the nanocellulose more attractive for the industry and the institutions.
\end{abstract}

In this study, a concise, critical state-of-the-art review on nanocellulose materials, manufacturing technologies, global producers and their current and future applications were studied and reported.

Keywords: Nanotechnology, nanocellulose, nanocomposite, wood, polymer

To cite this article (Atıf): YILDIRIM, N . (2018). Nanoteknoloji ve Geleceğin Çevreci Polimeri Nanoselüloz. Ormancılık Araştırma Dergisi, 5 (2), $185-195$.

DOI: $10.17568 /$ ogmoad. 419758

\section{Giriş}

Ülkemizde özellikle son yıllarda değerinin anlaşılmaya ve üzerine düşülmeye başlandığı konuların başında gelen Araştırma ve Geliştirme (Ar-Ge), tüm dünyada inovatif malzemelerin geliştirilmesinde ve ekonomiye olan direkt katkıları ile büyük önem taşımaktadır. İçlerinde Türkiye'nin de bulunduğu birçok ülke, Ar-Ge'ye eskisinden çok daha fazla değer vermekte ve politikalarını ArGe üzerine kurmaktadır. Aşağıda verilen şekilde (Şekil 1) Ekonomik İşbirliği ve Kalkınma Örgütü (OECD) tarafından hazırlanmış verilerden (URL-1) yararlanılarak bazı ülkelerin Ar-Ge'ye verdiği destekler 2015 yılı için milyar dolar cinsinden gösterilmektedir. 


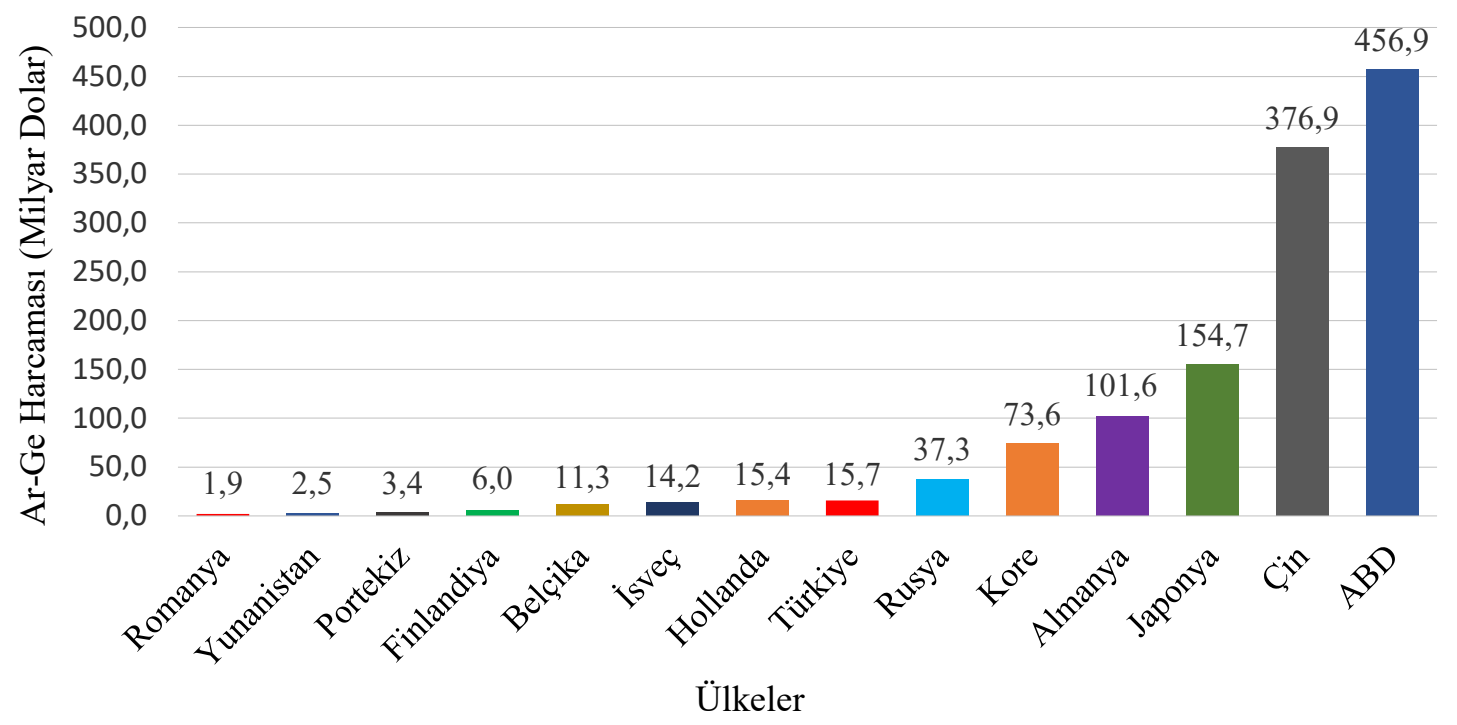

Şekil 1. Ülkelerin Ar-Ge destek miktarları (milyar dolar)

Figure 1. Countries' gross domestic spending on R\&D (billion dollars)

Şekil 1'de görüldüğü üzere birçok ülke gayri safi milli hasılasının ciddi bir kısmını Ar-Ge'ye ayırmakta ve bu miktarı her geçen gün artırmaya çalışmaktadır. Hâl böyleyken malzeme mühendisliği, metalürji mühendisliği, polimer mühendisliği, orman endüstri mühendisliği gibi malzeme ile doğrudan ilgili alanlara verilen desteklerin artması beklenmektedir. Her geçen gün Ar-Ge'ye yatırım miktarını artıran Türkiye'nin 2023 yılı hedefleri arasında yer alan Ar-Ge'ye önemin artırılması planlarında Ar-Ge'ye verilecek desteğin \% 3 olması hedeflenmektedir. Bu hedefe ulaşılması durumunda güncel destek 3-4 katı kadar artırılacak ve Türkiye'de Ar-Ge ve inovasyon daha önemli hale gelecektir.

Yeni nesil malzeme geliştirilmesinde bilimsel araştırmaların ve incelemelerin nano boyutta yapılmasına nanoteknoloji adı verilmektedir. Nano kelimesi bir uzunluk birimini ifade etmektedir. Bir nanometre $10^{-9}$ metreye eşittir; diğer bir deyişle, normal bir elmanın çapı yaklaşık olarak 80 milyon nanometredir veya günümüzde kullandığımız akıllı telefonların kalınlıkları 7-8 milyon nanometredir. Günümüzde uzmanlar geleneksellikten uzaklaşmış, yeni neslin ihtiyaçlarına cevap verilebilecek inovatif nanomalzemelerin geliştirilmesine odaklanmıştır. Bununla birlikte, toplumların eğitim seviyeleri, doğaya karşı sorumluluk duyguları ve farkındalık her geçen gün belirgin şekilde artmaktadır. Bu nedenle geliştirilen malzemelerin nanoteknoloji ile üretilmesinin yanı sıra çevreye dost ve yenilenebilir olması yeni neslin yeni talepleri arasındadır. Bu yüzden hem sektör hem de üniversiteler yenilenebilir çevreci malzemeler geliştiril- mesi üzerine çalışmalarını sıklaştırmışlardır.

Ağaç malzeme, beklenen bu taleplere cevap vermede yararlanılabilecek en iyi aday olarak ön plana çıkmış, birçok sektör ve üniversitelerde malzeme üretimlerinde kullanılmaya başlanmıştır. Ağaç malzeme ana bileşenler olarak selüloz, hemiselüloz ve ligninden oluşan doğal bir kompozit yapıya sahiptir. Ağaç malzemelerin kimyasal bileşenlerinden biri olan selüloz ağaç malzemeye verdiği direnç özellikleri ile ön plana çıkmaktadır. Selüloz nanoselüloz adı verilen binlerce, milyonlarca küçük yapıtaşından oluşmaktadır. Nanoselüloz ile ilgili bilgiler devam eden başlık altında detaylı bir şekilde verilmektedir.

Bu çalışmada, nanoteknoloji ve geleceğin çevreci polimeri nanoselüloz hakkında son yıllarda yapılan çalışmalardan detaylı bilgiler derlenmiş ve türleri, üretim teknolojileri, üretim kaynakları, güncel kullanım alanları ve gelecekteki kullanım alanları hakkında teknik bilgiler paylaşılmıştır.

\section{Nanomalzeme}

\subsection{Nanoselüloz}

Nanoselülozun tanımlanması için öncelikle ağaç malzemenin, selülozun ve en son nanoselüloz ve türevlerinin tanımlanması gerekmektedir. A ğaç malzeme bir önceki kısımda da bahsedildiği üzere ana bileşenler olarak selüloz, hemiselüloz ve ligninden oluşan bir biyokompozit malzemedir. Kompozit malzemeler iki veya daha fazla malzemeden oluşan melez malzemelerdir. Ağaç malzeme gibi lifli kompozitlerde eklenecek güçlendirici malze- 
melere yataklık yapma görevinde olan yapıya matris, güçlendirme (takviye) görevi üstlenen yapıya ise lif adı verilmektedir. Ağaç malzeme içerisinde hemiselüloz ve ligninler bir arada tutunarak hücre duvarlarındaki matrisi oluşturuken sellülozlar ise güçlendirici lifler olarak biyokompozit yapı içerisinde bulunurlar (Şekil 2).

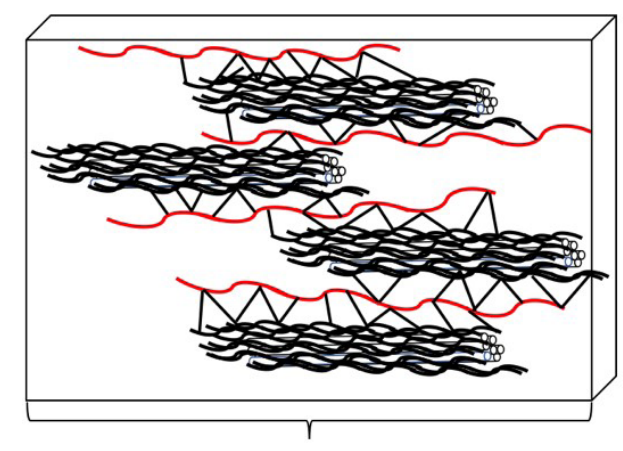

Hücre duvarını oluşturan kompozit yapı a) Hemiselüloz

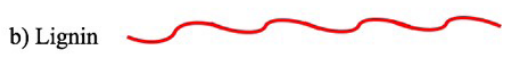

e) Selüloz nanolifler (SNL)

Şekil 2. Hücre duvarını oluşturan biyokompozit yapının demonstrasyonu

Figure 2. The demonstration of biocomposite sturucture that forms wood cell wall

Şekil 2'de verilen demonstrasyondan ve literatür çalışmalarından yola çıkılarak ağaç malzemenin liflerle güçlendirilmiş biyokompozit (fiber reinforced biocomposite (FRBC)) olarak tanımlanması yerinde olacaktır.

Kompozit yapı içerisinde güçlendirici görevi üstlenen selüloz, yeryüzünde fazla ve kolay bulunabilinen, yenilenebilir bir polimerdir (Hon, 1994). Bitkilerde hücre yapısının büyük bir bölümünü oluşturan başlıca kâğıt, yapay ipek gibi ürünlerin yapımında kullanılan bir karbonhidrat olarak bilinmektedir. Selüloz çoğunlukla odun hücre duvarında daha önce de bahsedildiği üzere lignin ve diğer polisakkaritler (hemiselüloz) ile birlikte bulunmaktadır. Kimyasal yapı olarak selüloz, belirli sayıda glikoz moleküllerinin bir eter köprüsü ile bağlanması sonucunda meydana gelmiş düz (doğrusal) ve uzun zincirli doğal bir polimerdir. Selüloz polimerini ise bir araya gelmiş nanoselülozlar (Şekil 2) oluşturmaktadır. Dünya genelinde birçok araştırmacı nanoselüloz üzerine çalışmalarını artırmış ve nanoselülozu kompozit malzeme içerisinde matris ve güçlendirici malzeme olarak kullanmaya başlamıştır. Günümüzde selüloz polimerinin yarısından fazlası ağaç malzemeden elde edilmektedir fakat farklı üretim kaynakları da bulunmaktadır. Bu kaynaklar bir sonraki başlıkta detaylandırılmıştır.

\subsection{Nanoselüloz üretimi için başlıca selüloz kaynakları}

\subsubsection{Ağaç malzeme}

Birçok doğal kaynaktan elde edilebilen nanoselüloz için ağaç malzeme bol miktarda bulunan kay- nakların başında gelmektedir. 2015 yılı verilerine göre dünya üzerinde 3,99 milyar hektar (Keenan ve ark., 2015) orman alanının bulunması, nanoselüloz için sürdürülebilir kaynakların bulunduğunun bir göstergesidir. Ağaç malzemeden nanoselüloz üretiminde genel olarak, selüloz nanopartiküllerin ekstrasiyonu lignin ve hemiselülozun uzaklaştırılması yani saflaştırılması ile gerçekleştirilmektedir.

\subsubsection{Bitki}

Bitkiler başlıca selüloz kaynaklarından biridir. Selüloz nanopartiküllerin ekstraksiyonu için pamuk, buğday samanı, patates yumruları, şeker pancarı gibi kaynaklar kullanılabilir. Nasim ve arkadaşları 2014 yılında aldıkları patentte bitkilerden nanoselülozun ön kimyasal işlemsiz üretilebileceğini belirtmişlerdir (Nasim ve ark., 2014). Günümüzde özellikle tekstil sektöründeki hasat ürün işlenmesi için güçlü bir alt yapının varlığı, nanoselüloz üretimi için bitkileri çekici hâle getirmiştir.

\subsubsection{Tulumlular}

Tulumlular, selüloz mikrolif eldesi için kullanılan bir hayvan türüdür. Bir protein matrisine gömülmüş selüloz mikroliflerden oluşan bir örteneğe (kabuğa) sahip bir deniz hayvanı ailesidir. Olgunlaşma döneminde oluşan bu derimsi örtenek mikrolif selüloz kaynağı olarak kullanılmaktadır. Selüloz mikrolifler, Ascidiacea sınıfının altında bulunan Phlebobranchia ve Stolidobranchia alt siniflarında bulunan Ciona intetinalis, Ascidia sp. ve Halocynthia, Styela Plicate türlerinden elde edilirler (URL-2). 


\subsubsection{Algler}

Çeşitli alg türleri (yeşil, gri, kırmızı vb.) hücre duvarlarında selüloz mikrolif üretmektedir. Chen ve arkadaşları başarılı bir şekilde Gelidium elegans kırmızı alglerinde nanoselüloz üretmişlerdir (Chen ve ark., 2016). Ürettikleri nanoselülozların termal özelliklerinin kompozitler için uygun olduğunu belirlemişlerdir.

Türe özgü gerçekleşen biyosentez işleminden dolayı üretilen selüloz mikrolif yapılarında önemli farklılıklar bulunabilmektedir. Kullanılan diğer alg türleri ise Micrasterias denticulata, Micrasterias rotate, Valonia, Caldophora ve Boergesenia'dir.

\subsubsection{Bakteriler}

Selüloz üretebilen bakterilerden üzerinde en çalış1lanı Gluconacetobacter xylinus olarak bilinmektedir (Kuo ve ark., 2016). Özel kültür koşulları altında geliştirilen bakteriler, mikrolif selüloz ve \%97 oranında sudan oluşan ince bir jel (pelikül) ürete- rek selüloz mikrolif salgılamaktadır. Bakterilerin neden selüloz salgıladığı henüz belirsizdir, ancak yaşamlarını devam ettirebilmek amacıyla ultraviyole 1şığa, mantara, mayalara ve diğer organizmalara karşı salgıladıkları tahmin edilmektedir. Bakteriyel mikroliflerin en büyük avantajı, mikrolif oluşumunu ve kristalleşmeyi değiştirmek için kültürleme koşullarının ayarlanmasının mümkün olmasidır (Jozala ve ark., 2016).

\subsection{Nanoselüloz türleri ve tanımları}

Yapılan pek çok çalışmada elde edilen türler, ürünün boyutuna (nano, micro) ve kaynağına (odun, bitki, bakteri vb.) göre isimlendirilmektedir. Elde edilen her tanecik tipi birbirinden farklı olmakla birlikte, karakteristik ölçülere, morfolojilere, kristalliğe ve özelliklere sahiptir. Yaygın bilinen türler; selüloz nanolifler (SNL), selüloz nanokristaller (SNK), bakteriyel nanoselüloz (BNS), tunikat nano kristaller (t-SNK), ve alg nanoselüloz tanecikleridir (ANT). Tablo 1'de kısa tanımlamalar ve yaygın bilinen türler ile ilgili bilgiler verilmiştir.

Tablo 1. Yaygın bilinen nanoselüloz türleri ve kısa tanımları

Table 1. The well-known nanocellulose types and abbreviations

\begin{tabular}{|c|c|c|}
\hline Adlandirma & Kisaltma & Tanımlama \\
\hline Selüloz mikrokristal & SMK & Mikro boyutlu ölçeklenmiş parçacıklar. \\
\hline Selüloz mikrolifler & SML & Mekanik arıtma ile üretilen mikro boyuttaki lifler \\
\hline Selüloz nanopartiküller & SNP & $\begin{array}{l}\text { Nano ölçekteki en az bir boyuta sahip nano boyutlu selülozların tüm fark- } \\
\text { l1 formları. }\end{array}$ \\
\hline Selüloz nanolifler & SNL & Mekanik arıtma ile üretilen nano boyuttaki liflerdir. \\
\hline Selüloz nanokristaller & SNK & $\begin{array}{l}\text { Genellikle asit hidrolizi veya ekstrasyonu ile üretilmiş nano boyuttaki } \\
\text { kristallerdir. }\end{array}$ \\
\hline $\begin{array}{l}\text { Belirli kaynaktan elde } \\
\text { edilen selüloz nanokris- } \\
\text { taller }\end{array}$ & $\mathrm{x}$-SNK & $\begin{array}{l}\text { Genellikle belirli kaynaktan asit hidrolizi veya ekstrasyonu ile üretilmiş } \\
\text { nano boyuttaki kristallerdir. En yaygın kullanımı Tunikat organizmaları } \\
\text { için t-SNK'dır. }\end{array}$ \\
\hline $\begin{array}{l}\text { Bakterilerden üretien } \\
\text { nanoselüloz }\end{array}$ & $\mathrm{BNS}$ & $\begin{array}{l}\text { Genellikle gluconacetobacter, Sarcina spp. gibi bakterilerden asit hidro- } \\
\text { lizi veya ekstrasyonu ile üretilmiş nano boyuttaki kristallerdir. }\end{array}$ \\
\hline
\end{tabular}

Tablo 1'de verilen yaygın türlerden farklı olarak elde ediliş şekillerine ve kaynaklarına göre daha birçok adlandırma bulunmaktadaır. Bu çalışmada en yaygın türlerin isimleri ve tanımlamaları verilmiştir.

\subsubsection{Selüloz nanoliffler (SNL)}

Selüloz nanolifler, lifleşmeye olanak sağlayan özel tekniklerin odun ve bitki liflerinin mekaniksel öğütülmesinde yer almasıyla üretilebilen ince selüloz lifleridir (Johnson ve ark., 2009; Saito ve ark., 2006). SNL odun ve bitki selülozlarının biyosentetik işleminde başlangıç liflerinin hatırlatıcısı gibidir. 13 kristal yapısında dizilmiş 36 selüloz zincirinden oluştuğu, dairesel kesite sahip olduğu, yüksek en-boy oranına sahip olduğu (4-20 nano- metre genişlik, 500-2.000 nanometre uzunluk) ve amorf (düzensiz) ve kristal (düzenli) yapılar içerdiği bilinmektedir (Moon ve ark., 2010).

Şekil 3'te araştırmacının önceki çalışmalarından (Yildirim ve ark., 2014) TEM (Taramalı Elektron Mikroskobu) görüntüsü alınmış SNL’e bir örnek verilmektedir.

Şekil 3'te görüldüğü gibi mekaniksel yöntemler ile üretilen SNL çapları 20 nanometre ve 100 nanometre arasında değişmektedir.

\subsubsection{Selüloz nanokristaller (SNK)}

Selüloz nanokristaller ağaç lifi, bitki lifi, selüloz mikrokristal, selüloz mikrolifler, veya selüloz na- 


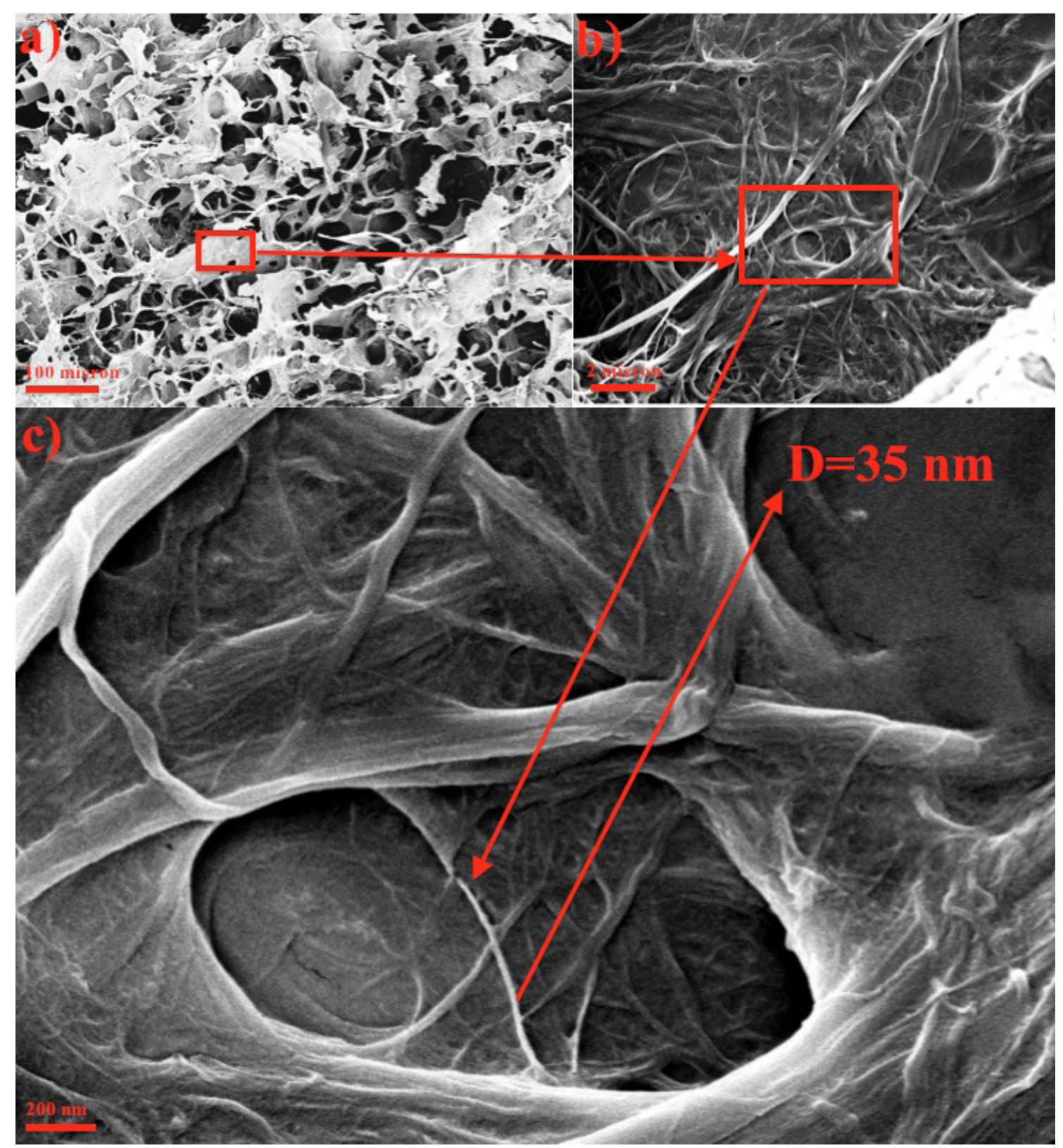

Şekil 3. Selüloz nanoliflerin TEM görüntüsü ve lif çap ölçümleri a, b, c (D = lif çapı)

Figure 3. The SEM images of cellulose nanofibrils and fibril diameter measurements $a, b, c(D=$ fibril diameter)

nolifferin asit hidrolizi sonrası elde edilebilen ince bir çubuk, kıl veya prinç tanesi şeklindeki yapılardır (Rodriguez ve ark., 2006; Stephanie ve ark., 2005). Şekil 4'te bu taneciklerin atomik kuvvet mikroskobu (AKM) kullanılarak alınmış olan 3 boyutlu görüntüsü verilmektedir. Ölçüm derinliği maksimum 100 nanometrelik bir derinlikte gerçekleştirilmiştir, bu da tanecik çaplarının 100 nanometreden daha küçük olduğunu göstermektedir.

$\mathrm{Bu}$ parçacıklar literatürde, nanokristalin selüloz, selüloz nano çubuklar ve selüloz mikro kristalleri olarak isimlendirilmiştir. Selüloz nanokristallerin yüksek en-boy oranına (3-5 nanometre genişlik,

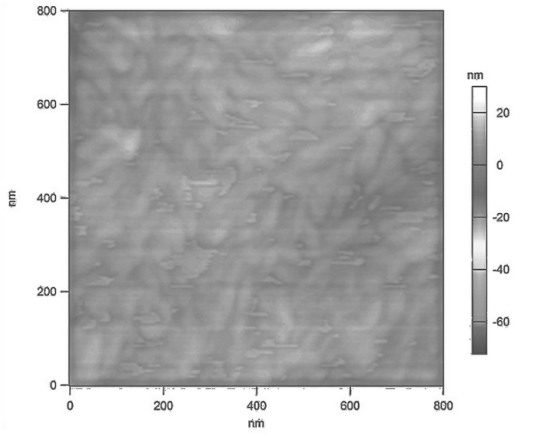

Şekil 4. Selüloz nanokristallerin AKM görüntüsü Figure 4. The AFM images of cellulose nanocrystals 
50-500 nanometre uzunluk), yüksek oranda kristalimsi yapıya sahip olduğu (\% 54-88) ve 13 Kristal yapısının büyük bir kısmını içerdiği bilinmektedir (\% 68-94). Bunlara ek olarak yine asit hidrolizi kullanılmasına rağmen farklı boyutlarda (en, boy) selüloz nanokristaller de üretilmiştir (Bai ve ark., 2009; Rodriguez ve ark., 2006). Eğer hidroliz yetersiz ise azalan kristallik ve değişen tanecik morfolojisinin sonucu olarak amorf bölgelerde tamamlanmamış ç1karılma bölgeleri meydana gelebilir. Hidrolizin şiddetinin arttırılmasıyla (reaksiyon süresinin uzatılması, güçlü asit kullanılması veya kullanılan asidin miktarının artırılması gibi) kristalin selülozu depolimerize etmek mümkündür. Hidroliz şiddetinin artmasıyla tanecik uzunluğu düşecek (Stephanie ve ark., 2005) bu da en-boy oranı azaltacaktır. Hatta bu işlem küre şeklindeki tanecik yapısının oluşmasına sebebiyet vermektedir.

\subsubsection{Bakteriyel Nanoselüloz (BNS)}

BNS mikroorganizmalar tarafından hücre dışında üretilir. Bu mikroorganizmalar arasında en verimlisi olarak bilinen Gluconacetobacter xylinum'dur. Bakteriyel nanoselüloz, bitki ve odun gibi kaynaklardan farklı olarak asit hidrolizi öncesi ön işlem gerekmeden saf olarak sentezlenir (Abitbol ve ark., 2016).

Tipik olarak, Acetobacter bakterisinden üretilen mikrolifler dikdörtgensel kesite (6-10 nanometre'ye 30-50 nanometre) sahip olmakla beraber $1 \alpha$ kristal yapısındadır (Moon ve ark., 2010).

\subsubsection{Tunikat selüloz nanokristaller (t-SNK)}

Tunikatların asit hidrolizi sonucu elde edilmesiyle oluşan tanecikler t-SNK olarak adlandırılır. Bazı kaynaklarda tunikat selüloz nanokristaller parça morfolojisi, kristallik yapısı ve mekaniksel özelliklerinden dolayı diğer nanokristallerden ayrı olarak incelenmiştir. Tunikat selüloz nanokristallerin en büyük avantajı yüksek kristalimsi yapıya ve enboy oranına sahip olmasıdır.

İdeal morfolojileri paralelkenar şeklinde kesite sahip olması ve $1 \beta$ kristal yapıda olmasıdır fakat asit hidrolizi sırasında tanecikle aşınmakta ve biçimsiz bir şekil ortaya çıkmaktadır (Helbert ve ark., 1998).

\subsubsection{Alg nanoselüloz tanecikleri (ANT)}

Alg selüloz tanecikleri çeşitli alglerin hücre duvarlarından asit hidrolizi ve mekaniksel işlemler uygulanarak elde edilen selüloz mikroliflerdir.

Alg türüne, kullanılan üretim yöntemine ve üretim parametlerine bağlı olarak elde edilen selüloz lif- ler, mikron uzunluğunda ve geniş en-boy oranına sahiptir (Moon ve ark., 2010).

\subsection{Nanoselüloz üretimi}

\subsubsection{Selüloz taneciklerinin izolasyonu}

Çeşitli selüloz kaynaklarından selüloz parçacıklarının izolasyonu iki aşamada gerçekleşmektedir. İlk aşama kaynak malzemelerin saflaştırılma ve homojenleştirilmesini içermektedir. Bu ön işlem sonraki işlemlerde daha tutarlı bir şekilde reaksiyon meydana gelmesine yardımcı olur. Bu özel ön işlem selüloz kaynağına bağlı olarak farklıl1k göstermektedir (Moon ve ark., 2010).

Ağaç ve bitkiler için ön işlemler, matris malzemelerinin (hemiselüloz, lignin, vb.) tamamen ya da kısmi olarak çıkarılmasını ve ayrı ayrı tamamlayıc1 liflerin (odun lifi, bitki lifi) izolasyonunu içerir. Tulumlular için ön işlem örteneğin (kabuğun) hayvandan izole edilmesini ve matris proteinin çıkarılması ile selüloz liflerinin ayrı ayrı izolasyonunu içerir. Alg selüloz kaynakları için ön işlem, kültür oluşturma metodunu ve alg duvar matris materyalinin kaldırılması için saflaştırma adımlarını içerir. Bakteriyel nanoselüloz için ön işlemler, selüloz mikrolif gelişimi için kültür oluşturma metotlarının yanı sıra bakteri ve diğer ortamların kaldırılması için yıkanmasını içermektedir.

İkinci aşama, bu saflaştırılmış (ön işlem görmüş) selüloz malzemelerin mikrolif, nanolif veya kristalin bileşenlerine ayrılmasını içerir (Moon ve ark., 2010). Bu aşamada genel olarak mekaniksel işlem ve asit hidrolizi iki temel ayrıştırma tekniği olarak gösterilirken sadece birkaç çalışmada ultrasonik (Chen ve ark., 2011) ve enzimatik (Meyabadi ve Dadashian, 2012; Imai ve ark., 1998) işlemler de temel ayrıştırma tekniği olarak gösterilmiştir. Ayrıca kullanılan teknik ne olursa olsun, ham malzemenin bazı ön işlem saflaştırma aşamalarının her zaman gerekli olduğu ve son ürün kalitesi bakımından faydalı olduğu belirtilmiştir (Li ve ark., 2015).

\subsubsection{Mekanik işlem}

Çeşitli ham materyallerden selüloz liflerin eldesi için pek çok mekanik işlem kullanılmıştır. Bunlar çoğunlukla selüloz liflerin boyuna ekseninde enine yarılmalara sebep olup yüksek kesme gradyanları üreten arıtma, öğütme, yüksek basınçta homojenizasyon, soğuk ufalama ve yüksek yoğunluklu ultrasonik gibi işlemlerdir (Rebouillat ve Pla, 2013).

$\mathrm{Bu}$ aşamada, lifler genellikle yüksek basınçlı homojenizatör veya özel tasarlanmış disklerin içinde gerçekleşen öğütme ile birbirinden ayrılır. Elde edilen ürün selüloz mikrolif, selüloz nanolif, nano- 
selüloz olarak adlandırılmaktadır (Turbak ve ark.; 1983; Herrick ve ark., 1983). Mekaniksel üretim yönteminde, doğal bir ögütme veya ayırma gerçekleştiği için son ürün içerisinde farklı çaplara ve boylara sahip mikro ve nano boyutta lifler elde edilebilmektedir. Buna ek olarak, parçalanma her ne kadar ilk önce amorf kısımlarda da olsa son ürün içinde değişik oranlarda kalan amorf yapılar kristallik derecesini düşürmektedir. Üretim sırasındaki bazı zorluklara rağmen yüksek polimerizasyon derecesi ve en boy oranına (aspect ratio) sahip olan selüloz nanolif ve mikroliflerinin, lif uzunlukları boyunca daha fazla fonksiyonel gruba ev sahipliği yapmas1, malzeme modifikasyonlarında veya yeni kompozitlerin oluşturulmasında artı bir özellik olarak göze çarpmaktadır.

\subsubsection{Asit hidrolizi}

Asit hidrolizi, kristalimsi partikülleri selüloz kaynaklarından (bitki lifi, odun lifi, tulumlular, alg ve bakteri) elde etmek için kullanılmaktadır. Bu işlem kısaca selüloz mikro/nanoliflerin içindeki amorf bölgelerin hidroliz edilmesi (ayrıştırılması) olarak açıklanabilir. Asit hidrolizi, kuvvetli asidik şartlarda gerçekleşmektedir. Farklı asitlerin kullanılabildiği bu üretim yönteminde amorf yapıda olan kısımlar polimer zincirinden parçalanarak çıkartıldığı için polimerizasyon derecesi düşürülmekte, fakat kristallik derecesi yüksek nanoselülozlar elde edilmektedir.

Nanoselüloz üretiminde farklı asit türleri (sülfürik, hidroklorik, fosforik, hidrobromik ve maleik asitler) kullanılmaktadır ve bu asitler selüloz nano kristallerde (SNK) farklı özellik ve morfolojilere neden olmaktadır (Li ve ark., 2015). Asit hidrolizinde hidroklorik asit $(\mathrm{HCl})$ kullanılırsa ve elde edilen ürün ölçüleri mikro seviyede olursa selüloz mikrokristal (SMK) olarak adlandırılmaktadır. Hidroliz işleminde ayrıca sülfürik asit $\left(\mathrm{H}_{2} \mathrm{SO}_{4}\right)$ de kullanılmaktadır ve kullanılan bu asit, selüloz üzerinde sülfat ester gruplarının oluşmasına neden olmaktadır. Bu da liflerin ayrımını ve stabilizasyonu kolaylaştırıcı bir rol oynamaktadır (Rånby, 1949; Revol ve ark., 1994).

Asit hidrolizi işleminin devamı olarak nanoparçacıkların ayrışması ve olabildiğince tek parçacıklar hâline gelmesi için ultrasonik ses dalgaları uygulanmakta, yapı parçalanmakta, kısa çubuğumsu parçalar birbirinden ayrıșmaktdır. Elde edilen ürün selüloz kristalitleri, selüloz nanokristalitleri veya nanokristalin selüloz (SNK) olarak adlandırılmaktadır. Elde edilen bu ürün amorf yapıların imkân çerçevesi içinde maksimum seviyede parçalanması ve uzaklaştırılması ile elde edildiğinden yüksek kristallik derecesine sahipken uzun polimer zincirlerinin parçalanması sebebi ile ise düşük en boy oranına sahiptir (Battista, 1950; Fleming ve ark., 2001; Lima ve Borsali, 2004).

Nanoselüloz eldesi için kullanılan yöntemler ayrı ayrı uygulanabildiği gibi istenilen tanecik morfolojisine göre sırasıyla veya kombine halde uygulanabilir. Örneğin selüloz nanolifler, soya fasülyesinden Wang ve Sain (Wang ve Sain, 2007) tarafından kimyasal-mekanik yöntem ile elde edilmiştir (Tablo 2). Elde edilen nano liflerin 50-100 nanometre (nm) çapında ve birkaç bin nanometre uzunluğunda olduğu belirlenmiştir.

Bir diğer çalışmada Alemdar ve Sain (2008) kimyasal işlem ile buğday samanından selüloz nanolifler elde etmiştir. Ayrıca kimyasal işlem görmüş liflere mekanik işlem de uygulanmıştır. Elde edilen nano liflerin 10-80 nanometre (nm) çapında ve birkaç bin nanometre uzunluğunda olduğu belirlenmiştir.

Tablo 2. Kimyasal-mekanik yöntem ile nanolif eldesi işlem basamakları (Wang ve Sain., 2007). Table 2. Nanofibril manufacturing process steps by chemo-mechanical method

\begin{tabular}{cl}
\hline $\begin{array}{c}\text { Adım } \\
\text { Sayıs1 }\end{array}$ & \multicolumn{1}{c}{ Adım Tanımı } \\
\hline 1 & Hammade (soya fasülyesi) \\
2 & Ön işlem (Ağırlıç̧a \%17,5'lik sodyum hidroksit (NaOH), 2 saat boyunca) \\
3 & Asit hidrolizi (1 Molar hidroklorik asit, $70-80^{\circ}, 2$ saat boyunca) \\
4 & Alkali işlem (A ğırlıkça $\% 2$ sodyum hidroksit $(\mathrm{NaOH}), 70-80^{\circ}, 2$ saat boyunca) \\
5 & Sivı azot içinde soğuk ufalama \\
6 & Yüksek basıç̧ta defibrilasyon \\
\hline
\end{tabular}

Üretim şekillerini özetleyecek olursak, nanoselülozlar en az bir boyutu nano seviyede olmak şartı ile lif şeklinde ise selüloz nanolif (SNL), kristalin yapıda ise selüloz nanokristal (SNK), bakterilerden üretilmiş ise bakteriyel nanoselüloz (BNS) adını alırlar. Farklı isimlendirmeler de ya- pılmıştır, fakat en genel kullanıma sahip olanlar bunlardir.

Nanoselülozlar mekanik ve kimyasal yöntemlerle üretilebilir. Mekanik yöntemlerle üretimde, ağaç malzeme selülozunda bulunan makro ve mikro 
yapıdaki lifler öğütme ve mekanik baskı uygulanması yoluyla nanolifler haline getirilerek nanoselüloz üretimi gerçekleştirilebilir (Cai ve ark., 2013) ve bu tür nanoselülozlara çalışmanın önceki kısımlarında belirtildiği gibi selüloz nanolif (SNF) adı verilir. Kimyasal yollar (asit hidrolizi ve/veya enzimatik hidroliz) ile liflerin parçalanıp kristal hâline dönüştürülmesi ile de selüloz nanokristaller (SNL) elde edilebilir. Kimyasal yollar ile SNK'lar elde edildiği gibi SNL'ler de elde edilebilir. Bunlara ek olarak hem kimyasal hem mekanik yöntem aynı anda uygulanabilir veya sıcaklık ve basınç parametreleri de eklenerek yeni üretim kombinasyonları oluşturulabilir.

\subsection{Nanoselüloz kullanım alanları ve küresel üreticileri}

Nanoselüloz polimerinin doğal ve organik olmas1nın yanı sıra diğer malzemelere göre performans avantajları da bulunmaktadır. Yoğunluklarının az olmasına rağmen gösterdikleri yüksek direnç diğer malzemelere nazaran geniş kullanım alanlarında kullanılmasına yardımcı olmaktadır. Çelikten birkaç kat hafif olması ve çelik kadar yüksek mekanik özellikler gösterebilme yetisi araştırmacıların dikkatini çekmiştir (Lee ve ark., 2014). Mekanik performans özelliklerinin yanı sıra stabil termal özellikler sağlaması da nanoselüloz polimerinin diğer malzemelere karşı gösterdiği başka bir avantajdır. Önceki çalışmalarda incelenen SNK'ların ve SNL'lerin isıl bozunma sicaklıklar1 $250{ }^{\circ} \mathrm{C}-350$ ${ }^{\circ} \mathrm{C}$ arasında bulunmuştur (Rebouillat ve Pla, 2013; Yildirim ve ark., 2014).

Tüm bu avantajlarının yanı sıra nanoselülozun da doğası gereği sahip olduğu bazı dezavantajlar bulunmaktadır. Ağaç malzemeden elde edilmesi dolayısı ile hydrophilic (suyu sever) karaktere sahip olan nanoselüloz aynı zamanda da yanabilen bir malzemedir. Araştırmacılar bu dezavantajlara çözümler üretmiş ve yangına, suya dayanaklı nanoselüloz malzemeler üretmişlerdir (Korhonen ve ark., 2011; Wicklein ve ark., 2014; Yildirim, 2018).

Yeni nesil nanoselüloz malzemeler taşıdıkları yaygın karakteristik özellikler sayesinde birçok kullanım alanında kendilerine yer bulabilmektedir. Tablo 3'te bu alanlar listelenmiştir.

Nanoselüloz bazlı malzemeler özellikle son yıllarda orman ürünleri alanında belirgin bir kullanım alanına sahiptir. Söz konusu malzemeler, kağıt yapımı ve güçlendirilmesinde (Campano ve ark., 2018); panel malzeme (Yildirim ve ark., 2014), köpük malzeme (Svagan ve ark., 2008), yanmaz yalıtım malzemeleri (Yildirim, 2018), tıp alanında yapay organ (Nimeskern ve ark., 2013), ve iyileştirici yapay deri üre-

Tablo 3. Nanoselüloz malzemelerin kullanıldığ 1 sektörler

Table 3. The current sectors in which nanocellulose is used

\begin{tabular}{llll}
\hline & Multidisipliner Sektörler & Orman Ürünleri Sektörü \\
\hline 3D Üretim & Yapı Malzemeleri & Polimerler & Plastik Mobilya Ürünleri \\
Tutkallar & Kozmetik & Elektronik & Kâğıt Teknolojileri \\
Kimyasallar & Savunma & Enerji & Panel Ürünler \\
Tarım & Araştırma & Plastikler & Paketleme \\
Otomobil & Filtreleme & Sağlık ve İlaç & Köpük Üretimleri \\
Biyoteknoloji & Besin Paketleme & Kompozit Malzemeler & Ambalajlama \\
\hline
\end{tabular}

timlerinde (Mualla ve ark., 2016) ve virüslere karş1 filtreleme kullanımında (Metreveli ve ark., 2014) kendine belirgin yer edinmiştir. Burada verilen kullanım alanları sadece birkaç örnekten ibarettir, günümüzde nanoselülozun kullanım alanı ise hayal edilenden daha yaygın hale gelmiştir.

Bu kullanım alanlarının talebini karşılayabilmek için küresel nanoselüloz üreticileri de her geçen gün artmaktadır (Tablo 4) (URL-3).

TAPPI (The Technical Associateion of Pulp and Paper Industry) çalışmalarından elde edilen 2015 yılı verilerinin verildiği Tablo 4'te görüldüğü üzere farklı ülkelerde selüloz nanolif (SNL) ve selüloz nanokristal (SNK) üretimi yapılmaktadır. Lif ve kâğıt teknolojileri tarihi güçlü olan, nanoselüloz farkındalığının yüksek olduğu ülkelerde birden çok üreticinin olması, nanoselüloza olan belirgin talebin göstergesidir.

\section{Sonuç ve Öneriler}

Yenilenebilir enerjiye, yenilenebilir enerji kaynaklarına, yenilenebilir ve çevre dostu malzemelere gün geçtikçe artmakta olan bir talep bulunmaktadır. Bu talep sadece bir moda olmaktan çıkmış, geleceğimiz adına zaruri bir ihtiyaç ve ayrıca ticari bir gerçeklik hâline gelmiştir. Bunun farkında olan birçok firma çevreci malzemelerin geliştirilmesine odaklanmış, Ar-Ge çalışmalarını hızlandırmış ve hâlihazırda ürettikleri malzemelere alternatif olan doğal malzemeler üretmeye, geliştirmeye başlamışlardır. Bu talebin karşılanmasında doğanın en 
Tablo 4. Küresel nanoselüloz üreticileri (2015 y1lı verileri)

Table 4. Global nanocellulose producers (2015)

\begin{tabular}{lcll}
\hline \multicolumn{1}{c}{ Üreten Merkez / Firma } & Ülke & \multicolumn{1}{c}{ Nanoselüloz türü / Kapasite } \\
\hline Alberta Innovates & Kanada & - & SNK - 20 kg/gün \\
American Process & A.B.D. & SNL - 0.5 ton/gün & SNK - 0.5 ton/gün \\
Bluegoose Biorefineries & Kanada & - & SNK - 10 kg/gün \\
Borregaard & Norveç & SNL - 1 ton/gün & - \\
Celluforce & Kanada & - & SNK - 1 ton/gün \\
CTP/FCBA & Fransa & SNL - 100 kg/gün & - \\
Daicel & Japonya & SNL - Laboratuvar Üretimi & - \\
FPInnovations & Kanada & SNL - Pilot Tesis & SNK - 3 kg/gün \\
Holmen (Melodea) & İsveç & - & SNK - 100 kg/gün \\
India Council for Ag. Research & Hindistan & - & SNK - 10 kg/gün \\
Innventia & İsveç & SNL - 100 kg/gün & - \\
Lulea University of Tech. & İsveç & SNL - Laboratuvar Üretimi & - \\
Melodea & İsrail & - & SNK - Pilot Tesis \\
NamiCell & Fransa & SNL - 100 kg/gün & - \\
Nippon Paper & Japonya & SNL - 150 kg/gün & - \\
Norske Skog & Norveç & SNL - Pilot Tesis & - \\
OjiPaper & Japonya & SNL - 100 kg/gün & - \\
Paperlogic & A.B.D. & SNL - 2 ton/gün & - \\
Stora Enso & Finlandiya & SNL - Ticarileşme aşamasinda & - \\
University of Maine & A.B.D. & SNL - 1 ton/gün & - \\
UPM & Finlandiya & SNL - Ticarileşme aşamasinda & - \\
Forest Products Laboratory & A.B.D. & SNL - Ticarileşme aşamasinda & - \\
VTT & Finlandiya & SNL - Pilot Tesis & SNK - 10 kg/gün \\
\hline & & &
\end{tabular}

büyük zenginliklerinden biri olan ağaç malzemenin kullanımı gerçekçi ve sürdürülebilir bir çözüm olarak ortaya çıkmaktadır. Ahşap esaslı nanoselülozlar yeni nesil malzemelerin geliştirilmesi ve üretilmesinde inovatif bir çözüm olacaktır. Nanoselülozun kullanılması ile otomobil sektöründe araçların hafifletilmesi, çevreye dost yenilenebilir inşaat malzemelerinin üretilmesi, gıda sektörü için kansorejen maddeler içermeyen ambalajlama paketlerinin geliştirilmesi, yapay organ geliştirilmesi gibi daha pek çok yenilik sağlanabilecektir.

Araştırmacıların, sektörün ve üniversitelerin nanoselüloz gibi geleceğin değerli polimerleri üzerine çalışmaları ve araştırma politikalarını çevreye duyarlı malzemeler üzerine yapmaları gerekmektedir.

\section{Teșekkür}

Yazar, çalışmasının literatür araştırmasını gerçekleştirirken yararlandığı Bursa Teknik Üniversitesi'ne (BTÜ) ve Maine Üniversitesi'ne (University of Maine) sağlamış oldukları basılı ve elektronik kaynaklarından dolayı teşekkür etmektedir.

Bu çalışma 3. Uluslararası Mühendislik Mimarlık ve Tasarım Kongresinde sözlü olarak sunulmuştur.

\section{Kaynaklar}

Alemdar A., and Sain, M. (2008). Isolation and characterization of nanofibers from agricultural residues: wheat straw and soy hulls. Bioresour. Technol. 99;1664-1671.

Abitbol, T., Rivkin, A., Cao, Y., Nevo, Y., Abraham, E., Ben-Shalom, T., Lapidot, S., Shoseyov, O. (2016). Nanocellulose, a tiny fiber with huge applications. Current opinion in biotechnology. 39;76-88.

Bai, W., Holbery J., and Li, K. C. (2009). A technique for production of nanocrystalline cellulose with a narrow size distribution. Cellulose. 16;455-466.

Battista, O.A. (1950). Hydrolysis and crystallization of cellulose. J. Ind. Eng. Chem. 42;502-7.

Cai Z., Rudie A.W., Stark N.M., Sabo R.C. and Ralph S.A. (2013). Chapter 6: New products and product categories" In the global forest sector: Changes, practices and prospects. Edited by Hansen E., Panwar R. and Vlosky R. 129-149. Boca Raton, FL: CRC Press.

Campano C., Merayo N., Balea A., Tarres Q., Aguilar M. D., Mutje P., Negro C., Blanco A. (2018). Mechanical and chemical dispersion of nanocelluloses to improve their reinforcing effect on recycled paper. Cellulose. 25;269280.

Chen, W. S., Yu, H., Liu, Yi., Hai, Y., Zhang, M., Chen, P. (2011). Isolation and characterization of cellulose 
nanofibers from four plant cellulose fibers using a chemical-ultrasonic process. Cellulose. 18;433-442.

Chen, Y. W., Lee, H. V., Juan, J. C., Phang S. M. (2016). Production of new cellulose material from red algae marine biomass Gelidium elegans. Carbohydr. Polym. 151;1210-1219.

Fleming, K., Gray, D.G., Matthews, S. (2001). Cellulose crystallites. Chemistry-A European Journal. 7;18311835.

Helbert W., Nishiyama Y., Okano T., and Sugiyama J. (1998). Molecular imaging of halocynthia papillosa cellulose. J. Struct. Biol. 124;42-50.

Herrick, F.W., Casebier, R.L., Hamilton, J.K., Sandberg, K.R. (1983). Microfibrillated Cellulose: Morphology and Accessibility. J. Appl. Polym. Sci. 37;797-813.

Hon, D. N. S. (1994). Cellulose: a random walk along its historical path. Cellulose . 1;1-25.

Imai, T., Boisset, C., Samejima, M., Igarashi, K., Sugiyama, J. (1998). Unidirectional processive action of cellobiohydrolase Cel7A on Valonia cellulose microcrystals. FEBS Letters. 432;113-116.

Johnson R. K., Zink-Sharp A., Renneckar S. H. and Glasser W.G. (2009). A new bio-based nanocomposite: fibrillated TEMPO-ozidized celluloses in hydroxypropylcellulose matrix. Cellulose. 16;227-238.

Jozala, A.F., de Lencastre-Novaes, L.C., Lopes, A.M., de Carvalho, S. E. V., Mazzola, P.G., Pessoa, A. Jr., Grotto, D., Gerenutti M., Chaud M. V. (2016). Appl. Microbiol Biotechnol. 100;2063-2072.

Keenan, J. R., Reams, G. A., Achard, F., Joberto, F. V., Grainger A., Lindquist E. (2015). Dynamics of global forest area: Results from the FAO global forest resources assessment 2015. Forest Ecology and Management. 352; 9-20.

Korhonen J. T., Kettunen M., Ras R. H. A., Ikkala O. (2011). Hydrophobic nanocelluose aerogels as floating, sustaniable, reusable and recyclable oil absorbents. Applied Materials and Interfaces. 3;1813-1816.

Kuo, C.H., Chen, J. H., Liou, B. K., Lee C. K. (2016). Utilization of acetate buffer to improve bacterial cellulose production by Gluconacetobacter xylinus. 53;98-103.

Lee K., Aitomaki Y., Berglund A. L., Oksman K., Bismarck A. (2014). On the use of nanocellulose as reinforcement in polymer matrix composites. Composites Science and Technology. 105;15-27.

Li, F., Mascheroni, E., and Piergiovanni, L. (2015) The potential of nanocellulose in the packaging field: a review. Packaging Technol. and Sci., 28;475-508.

Lima, M.M.D., Borsali, R. (2004). Rodlike cellulose microcrystals: Structure, Properties, and Applications,
Macromolecular Rapid Communications. 25;771-87.

Meyabadi, T. F. and Dadashian, F. (2012). Optimization of enzymatichydrolysis ofwaste cotton fibersfor nanoparticles productionusing response surface methodology. Fibers and Polymers. 13;313-321.

Metreveli, G., Wagberg, L., Emmoth, E., Belak, S., Stromme, M., Mihranyan, A. (2014). A size-exclusion nanocellulose filter paper fro virus removal. $\mathrm{Adv}$. $\mathrm{He}$ althc. Mater. 3;1546-1550.

Moon, R. J. Martini, A. Nairn, J. Simonsen, J. Youngblood, J. (2010). Cellulose nanomaterials review: structure, properties and nanocomposites. Chem. Soc. Rev. 40;3941-3944

Mualla, S. A., Farahat, R., Basmaji, P., de Olyveira, G. M., Costa, L. M. M., Oliveira, J. D. C., Francozo, G. B. (2016). Study on nanoskin ECM-bacterial cellulose wound healing. Journal of Biomaterials and Nanobiotechnology. 7; 9 pp.

Nasim, A., Kumar, A. P., James, M. D. (2014). Plant origin nanocellulose material, comprises nanocellulose particles or fibers derived from plant material having high hemicellulose content. Australian Government, Patent Publication number: AU2014353890.

Nimeskern, L., Martinez, A. H., Sudnberg, J., Gatenholm, P., Müller, R., Stok, K. S. (2013). Mechanical evaluation of bacterial nanocellulose as an implant material for ear cartilage replacement. J. Mech. Behav. Biomed. Mater. 22;12-21.

Rånby, B.G. (1949). Aqueous colloidal solutions of cellulose micelles. Acta Chemica Scandinavica. 3;649-50.

Rebouillat, S., and Pla, F. (2013). State of the Art Manufacturing and Engineering of Nanocellulose: A Review of Available Data and Industrial Applications. Journal of Biomaterials and Nanobiotechnology. 4;165-188.

Revol, J.F., Godbout, L., Dong, X.M., Gray, D.G., Chanzy, H. Maret, G. (1994). Chiral nematic suspensions of cellulose crystallites; phase separation and magnetic field orientation. Liquid Crystals, 16; 127-134.

Rodriguez, N. L. G., Thielemans W., Dufresne A. (2006). Sisal cellulose whiskers reinforced polyvinyl acetate nanocomposites. Cellulose. 3;261-270.

Saito T., Nishiyama Y., Putaux, J. L., Vignon M., Isogai A. (2006). Homogeneous suspensions of individualized microfibrils from TEMPO-catalyzed oxidation of native cellulose. Biomacromolecules. 7;1687-1691.

Stephanie, B. C., Roman, M., Gray, D. G. (2005). Effect of Reaction Conditions on the Properties and Behavior of Wood Cellulose Nanocrystal Suspensions. Biomacromolecules. 6;1048-1054.

Svagan, A.J., Samir, M.A.S.A., and Berglund, L.A. (2008), Biomimetic Foams of High Mecahanical Perfor- 
mance Based on Nanostructured Cell Walls Reinforced by Native Cellulose Nanofibrils. Advanced Materials, 20(7): 1263-1269.

Turbak, A.F., Snyder, F.W., Sandberg, K.R. (1983). Microfibrillated cellulose, a new cellulose product: properties, uses and commercial potential. J. Appl. Polym. Sci. $37 ; 815-27$.

(URL-1). Gross domestic spending on R\&D (Accessed: April 28, 2018). https://data.oecd.org/rd/gross-domesticspending-on-r-d.htm.

(URL-2). Tunicate Nanocellulose: Preperation and Applications. (Accessed: April 28, 2018). http://bpums.ac.ir/ UploadedFiles/gFiles/Tunicate_5a6f9e7f.pdf

(URL-3). Nanocellulose state of the industry (2015). (Accessed: April 28, 2018). http://www.tappinano.org/ media/1114/cellulose-nanomaterials-production-stateof-the-industry-dec-2015.pdf
Wang, B., and Sain, M. (2007). Dispersion of Soybean StockBased Nanofiber in a Plastic Matrix. Polymer International. 56;538-546.

Wicklein, B., Kocjan, A., Salazar-Alvarez, G., Carosio, F., Camino, G., Antonietti M., Bergström, L. (2014). Thermally insulating and fire-retardant lightweight anisotropic foams based on nanocellulose and graphene oxide. Nature Nanotechnology. 10;277-283.

Yildirim, N. Shaler, S. M. Gardner, D. J. Rice, R. Bousfield D. W. (2014). Cellulose nanofibrils (CNFs) Reinforced Starch Insulating Foams. Cellulose. 21;4337-4347.

Yildirim, N. (2018). Developing fire-retardant and water-repellent bio-structural panels using nanocellulose. MRS Communications, 8;1-9. 